\title{
Variation of carbon content among bacterial species under starvation condition
}

\author{
Marc Troussellier ${ }^{1, *}$, Marc Bouvy $^{2}$, Claude Courties ${ }^{1}$, Christine Dupuy ${ }^{1}$ \\ ${ }^{1}$ Laboratoire d'Hydrobiologie, UMR no. 5556 and URM no. 5, Université Montpellier II, F-34095 Montpellier Cedex 05, France \\ ${ }^{2}$ ORSTOM, 911 avenue Agropolis, BP 5045, F-34032 Montpellier Cedex 1, France
}

\begin{abstract}
To explore the variability of bacterial biomass conversion factors in aquatic environments, 5 marine and 5 non-marine bacterial strains were exposed to nutrient deprivation in artificial seawater and physiological ( $\mathrm{NaCl}, 9 \mathrm{~g} \mathrm{l}^{-1}$ ) water, respectively. Carbon content per cell $\left(C_{c}\right)$ and per volume $\left(C_{v}\right)$ were estimated from total cell number, particulate organic carbon and cell volume $(\mathrm{V})$ measurements after 0,7 , 15 and $28 \mathrm{~d}$ of starvation. While $C_{c}$ appeared to be rather constant (26.02 $\pm 1.08 \mathrm{fg} \mathrm{C}$ cell $^{-1}$; mean \pm standard error, $\mathrm{n}=50$ ) during starvation, $C_{v}$ showed a significant increase. In general, $C_{v}$ increased more rapidly in marine strains than in nonmarine strains. $C_{\mathrm{c}}$ and $V$ were not correlated, but a highly significant relationship between $C_{v}$ and $V$ was found. The non-linear relation was well fitted by a power function model $\left(\mathrm{r}^{2}=0.847, \mathrm{p}<0.0001\right)$. Parameters of the power function adjusted to marine or non-marine strains were not significantly different. We conclude that $C_{\mathrm{v}}$ and, to a lesser extent, $C_{c}$ were dependent on species and physiological status. However, it seems that the differences in $C_{\mathrm{v}}$ between marine and non-marine bacteria observed in this study and by others are not the consequence of different relationships between $C_{\mathrm{v}}$ and volume, but, more likely, of the low cell volume of marine bacteria and their ability to reduce their water content faster than can non-marine bacteria.
\end{abstract}

KEY WORDS: Bacteria $\cdot$ Carbon content - Starvation

To understand the trophodynamics or biogeochemical role of bacteria in aquatic ecosystems, several studies have focused on conversion factor estimation to transform bacterial abundance or biovolume into biomass. The reported values of carbon content per cell $\left(C_{\mathrm{c}}\right)$ or carbon content per volume $\left(C_{\mathrm{v}}\right)$ exhibit a large range of variation (e.g. see Ducklow \& Carlson 1992, Fagerbakke et al. 1996).

Such a large variability may be partly explained by the difficulty of obtaining precise and reproducible

\footnotetext{
·E-mail: troussel@hydrobio.univ-montp2.fr
}

biovolume measurements (Nagata \& Watanabe 1990). However, carbon content per cell values, which are not dependent on volume estimation, also show large variations. Several hypotheses have been proposed to explain the variation of the conversion factors: (1) differences in the taxonomic composition of bacterial communities, which may depend on sampling time and location (Nagata \& Watanabe 1990, Kroer 1994), and (2) differences in physiological states of bacterial cells (Nagata 1986), which may be related to the trophic status of the ecosystem. However, to our knowledge, these hypotheses have never been explicitly tested.

$C_{c}$ and $C_{v}$ values estimated from bacterial cultures are scarce (see Fagerbakke et al. 1996) and have been obtained from cells grown under rich nutritional conditions (culture) which are very different from oligotrophic conditions of marine waters (Roszak \& Colwell 1987). Low ambient substrate concentrations induce bacterial cell starvation, in particular resulting in cell size decrease (Morita 1993). This phenomenon seems to be experienced by a large number of bacterial cells in aquatic ecosystems, especially in the oceans (del Giorgio \& Scarborough 1995). So, as outlined by Norland (1993), it is important to know if the relationship between biomass and biovolume ( $C$ factor) can be described by a constant ratio or if it exhibits a size dependence.

In the present study, we measured $C_{\mathrm{c}}$ and $C_{\mathrm{v}}$ values for 5 marine and 5 non-marine strains exposed to nutritional deprivation, to evaluate (1) the differences in conversion factors among different bacterial strains, (2) the effect of starvation conditions on these factors, and (3) the relationship between these factors and cell volume.

Materials and methods. Bacterial strains and starvation conditions: The 5 bacterial strains of marine origin 
(Alteromonas nigrifaciens, A. rubra, A. tetraodonis, Vibrio campbellii and $V$. fischeri) were obtained from P. Lebaron, Laboratoire Arago, Banyuls sur Mer, France. The 5 strains designated non-marine bacteria (from enteric or freshwater origins) were obtained from the ATCC (Aeromonas hydrophyla ATCC 15467, Escherichia coli ATCC 14948) or were from our collection (Enterobacter cloacae, Pseudomonas putida, Salmonella typhimurium) and previously isolated from freshwater in the Montpellier (France) area.

Marine strains were maintained on marine agar 2216 (Difco, Detroit, $\mathrm{MI}$ ) at $20^{\circ} \mathrm{C}$. Other strains were maintained on nutrient agar (bioMérieux, Marcy l'Etoile) at $30^{\circ} \mathrm{C}$.

Before each assay, colonies from marine or non-marine strains were transferred to manine broth (marine broth 2216, Difco; $20^{\circ} \mathrm{C}$ ) or to trypcase-soy broth (bioMérieux; $37^{\circ} \mathrm{C}$ ), respectively, and incubated for $24 \mathrm{~h}$ (stationary phase).

The cultures were then harvested by centrifugation at $1000 \times g$ for $10 \mathrm{~min}$, washed twice with either sterile artificial seawater (ASW) (Seasalts, Sigma, St. Louis, $\mathrm{MO}$ ) for marine strains, or sterile physiological water (PW) (NaCl, 0.9\%, wt/vol) for non-marine strains. Sterilization of suspension solutions was completed by filtration through $0.22 \mu \mathrm{m}$ then $0.1 \mu \mathrm{m}$ pore-size filters (Nuclepore, Costar, Pleasanton, CA).

Appropriate volumes of cellular suspensions were then dispersed in $1000 \mathrm{~mL}$ of sterile ASW or PW (acidwashed bottles rinsed with sterile water), to obtain initial abundance of $10^{7}$ to $10^{8}$ cells $\mathrm{ml}^{-1}$. These microcosms were maintained at room temperature (ca $22 \pm$ $2^{\circ} \mathrm{C}$ ) on an orbital shaker (Rotatest 74403 , Bioblock Scientific, Illkirch) at $150 \mathrm{rpm}$.

Samples for analyses were taken just after inoculation (T0) and after 1 (T1), 7 (T2), 14 (T3), and 28 d (T4) of incubation.

Particulate organic carbon (POC) determination: At each sampling time, 3 replicate samples (50 ml) were withdrawn and filtered in a clean acid-washed and rinsed glass filter unit (Millipore) through 2 stacked precombusted $\left(450^{\circ} \mathrm{C}, \geq 4 \mathrm{~h}\right) \mathrm{GF} / \mathrm{F}$ glass fiber filters (Whatman, $25 \mathrm{~mm}$ ). Filters were dried at $60^{\circ} \mathrm{C}$ for $>24 \mathrm{~h}$ and were assayed on a Leco CHN analyzer. At the beginning of the experiment, three $50 \mathrm{ml}$ samples of suspension medium (ASW and PW) were filtered on 2 stacked precombusted GF/F filters to check for carbon contribution of suspension medium. At each time, 2 blank precombusted GF/F filters (no water filtered) were assayed. These control filters contained no measurable amounts of carbon. On the other hand, bacterial abundance (see hereafter) in each filtrate was estimated, showing that the 2 stacked filters retained at least $99 \%$ of bacterial cells in samples (data not shown).
Cell counts and biovolume determinations: Triplicate samples $(2 \mathrm{ml})$ were taken at each sampling time and fixed with $0.2 \mu \mathrm{m}$ filtered formaldehyde (final concentration $2 \%, \mathrm{vol} / \mathrm{vol}$ ). After 1 h of fixation, samples were stained with DAPI (final concentration $2.5 \mu \mathrm{g}$ $\mathrm{ml}^{-1}$ ) for $24 \mathrm{~h}$ at $5^{\circ} \mathrm{C}$ in the dark. At the end of staining time, cell abundance was immediately measured by flow cytometry (ACR 1400SP, Bruker-Spectrospin, Wissembourg, France) according to Troussellier et al. (1993)

At the same time, a subsample was filtered onto a black Nuclepore filter $(0.2 \mu \mathrm{m}$ pore size) which was stored at $5^{\circ} \mathrm{C}$ in the dark, and examined, within $48 \mathrm{~h}$, with an epifluorescence microscope (Olympus BH with a $100 \times$ UVFL iris objective) to determine size of DAPI stained bacteria. Photographs (Kodak Tmax ASA 400) were taken from 10 randomly selected fields, then projected onto a digitizer tablet (final magnification, $\times 5000$ ). Dimensions of 50 cells per sample were measured with a computer-assisted digitizer. Cell volume $(V)$ was calculated assuming that the shape of bacteria was spherical or cylindrical with hemispheric ends: $V=$ $\left(\pi w^{2} / 4\right)(l-w / 3)$, where $w$ is the width and $l$ is the length of the cell (Bratbak 1985).

Calibration was performed with microphotographs of a slide micrometer (Zeiss) and microspheres (Polysciences, Warrington, PA) of 0.51 and $0.75 \mu \mathrm{m}$ diameter.

Results. Changes in measured variables and computed conversion factors for marine and non-marine strains are reported in Figs. 1 \& 2, respectively. Cell abundances showed either a slow but significant decreasing trend with time (all marine strains, Aeromonas hydrophyla, and Enterobacter cloacae), or stability (the other non-marine strains). In all incubations the average POC and cell volume values also showed a significant decrease with time. The ratio between cell length and width decreased with decreasing average cell volume, with the exception of Vibrio fischeri cells which have an initial low ratio (Table 1 ). Thus, cells tended to be more coccoid during incubation.

Carbon content per cell $\left(C_{c}\right)$ : There was no significant increase or decrease of carbon content per cell $\left(C_{c}\right)$ with time, when the whole starvation period was taken into account (Figs. 1 \& 2). However, during the first $24 \mathrm{~h}$ or the first $7 \mathrm{~d}, C_{c}$ values generally showed a limited decrease and remained stable thereafter.

The small coefficient of variation associated with mean $C_{c}$ value of each strain confirms the fairly constant value of their cellular carbon density (Table 2). While significant differences among $C_{c}$ values of the different strains were detected by a 1 -way ANOVA ( $F$ value $=9.687 ; \mathrm{p}<0.0001)$, there was only a factor of 2.3 

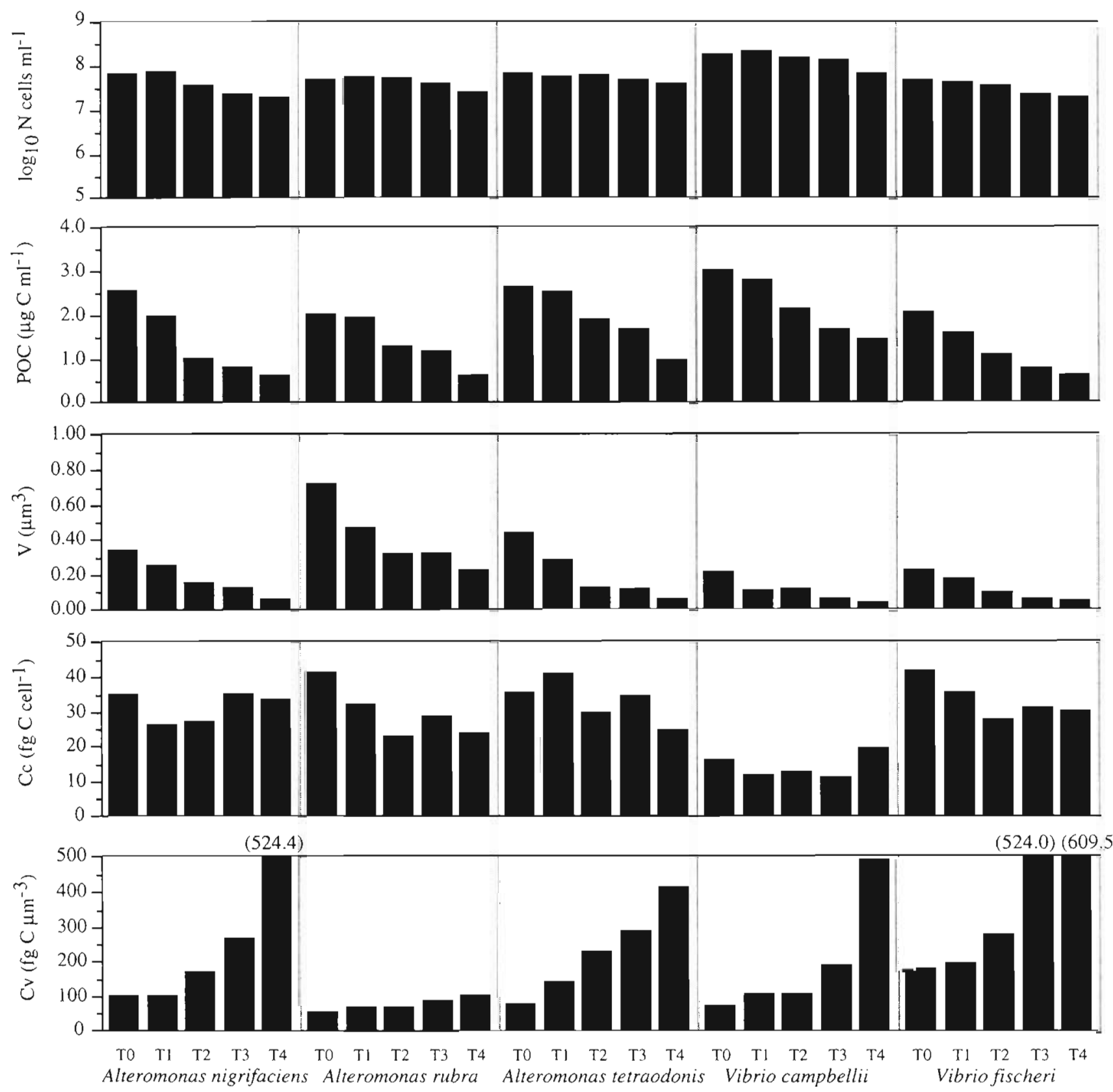

Fig. 1. Changes in cell abundances $(N)$, particulate organic carbon (POC), cell volume $(V)$, carbon content per cell $\left(C_{c}\right)$, and carbon density $\left(C_{\mathrm{y}}\right)$ for marine strains during starvation. Data are mean of triplicate measurements

between the lowest (14.51, Vibrio campbellii) and the highest $\left(33.45, V\right.$. fischeri) mean $C_{c}$ values.

Carbon content per cellular volume unit $\left(C_{v}\right)$ : In contrast, the amount of carbon per cellular volume unit $\left(C_{\mathrm{v}}\right)$ exhibited a significant increase during incubation for each strain (Figs. $1 \& 2$ ).

The slopes of the linear regression model between $C_{v}$ values and time showed that, except for Alteromonas rubra, marine strains have a higher $C_{\mathrm{v}}$ increase rate than non-marine strains (Table 3). At the end of the starvation period $(28 \mathrm{~d})$, there was a factor of 9 between the lowest (68.84, Escherichia coll) and the highest (609.52, Vibrio fischen) $C_{v}$ values.

$C_{c}$ and $C_{v}$ versus volume ( $V$ ) relationships: When $C_{c}$ values were plotted versus volume values, there was no significant relationship between the 2 variables (Fig. 3a), but plotting $C_{\mathrm{v}}$ versus volume values showed a strong non-linear relationship (Fig. 3 b) which was fit- 

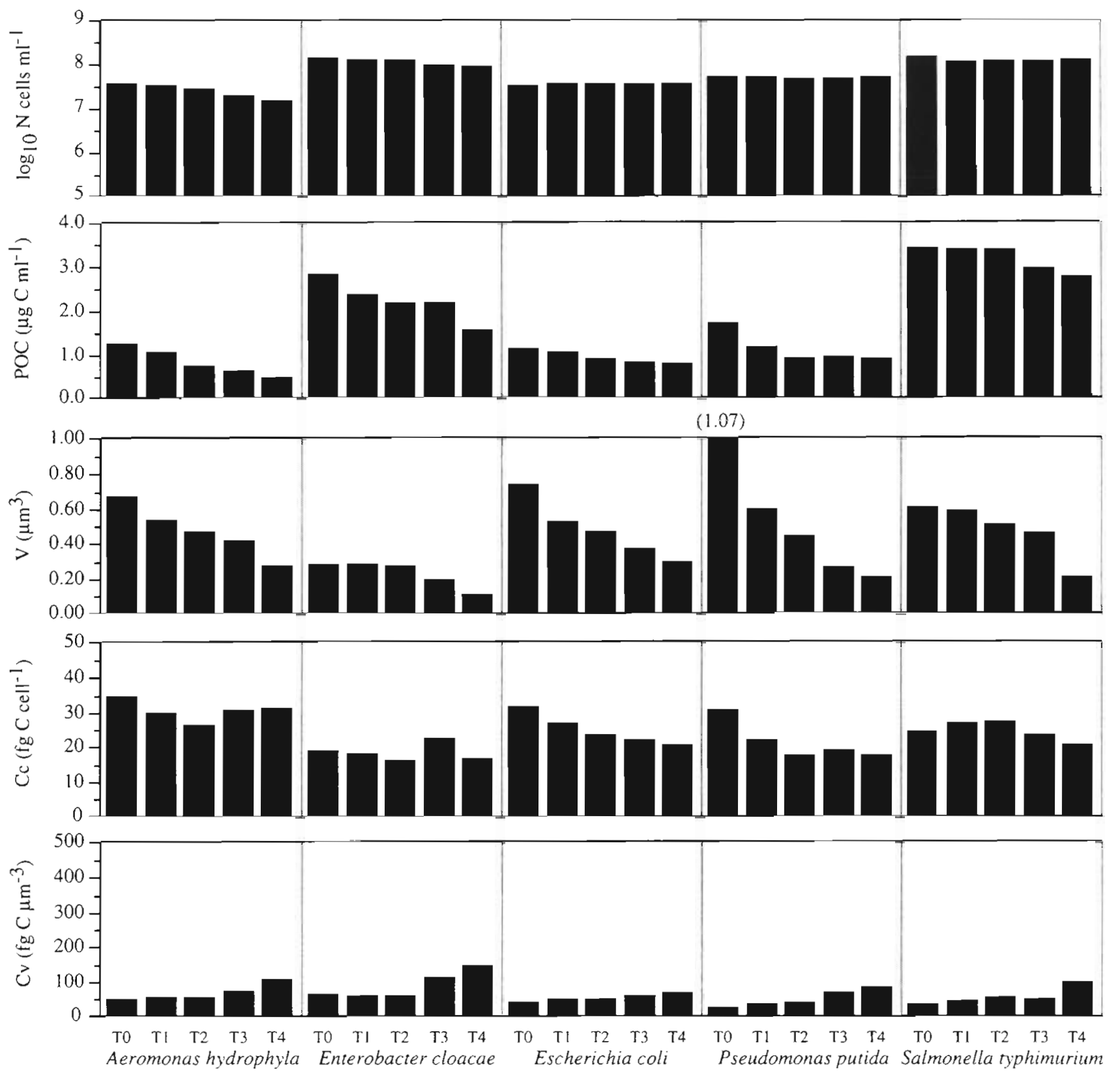

Fig. 2. Changes in cell abundances (N), particulate organic carbon (POC), cell volume $(V)$, carbon content per cell $\left(C_{c}\right)$, and carbon density $\left(C_{\mathrm{v}}\right)$ for non-marine strains during starvation. Data are mean of triplicate measurements

ted by the following power function $\left(C_{\mathrm{v}}=\alpha V^{\beta}\right)$ :

$$
C_{v}=25.73 V^{-0981}\left(r^{2}=0.847, \mathrm{p}<0.0001, \mathrm{n}=50\right)
$$

The $95 \%$ confidence intervals (lower and upper) for $\alpha$ and $\beta$ are: $\alpha, 21.54$ and $30.22 ; \beta,-1.110$ and -0.867 .

This equation was obtained from the major axis regression method applied to log-transformed variables, because there was error associated with the measurement of both variables of the model (Sokal \& Rohlf 1981) and because the data displayed a bivariate log- normal distribution. However, as underlined by Jackson \& Somers (1991), the analysis of association between 2 variables $x$ and $z$, where $z=y / x$, may result in an 'artificial' correlation because of the lack of independence between the ratio and its denominator. Thus, in this case, the null value, against which a sample correlation is to be tested, is not zero, but the correlation found after, and thus generated by, the transformation (Chayes 1971). As recommended by Jackson \& Somers (1991), we used a randomization test (based 
Table 1. Mean length $(L)$ and width $(W)$ (in $\mu \mathrm{m}$; SD in parentheses) and shape factor $(F=L / W)$ values of each strain at the beginning (TO) and at the end (T4) of starvation experiments

\begin{tabular}{|lcccc|}
\hline Bacterial strain & Time & Length & Width & $F$ \\
\hline Marine & & & & \\
Alteromonas nigrifaciens & T0 & $1.13(0.45)$ & $0.70(0.05)$ & 1.614 \\
& T4 & $0.52(0.22)$ & $0.36(0.14)$ & 1.445 \\
Alteromonas rubra & T0 & $1.69(0.46)$ & $0.79(0.05)$ & 2.140 \\
& T4 & $0.88(0.27)$ & $0.63(0.13)$ & 1.391 \\
Alteromonas tetraodonis & T0 & $1.43(0.59)$ & $0.62(0.16)$ & 2.314 \\
& T4 & $0.57(0.16)$ & $0.42(0.10)$ & 1.371 \\
Vibrio campbellii & T0 & $0.99(0.39)$ & $0.58(0.08)$ & 1.701 \\
Vibrio fischeri & T4 & $0.49(0.09)$ & $0.38(0.07)$ & 1.280 \\
Non-marine & T0 & $0.86(0.23)$ & $0.66(0.12)$ & 1.312 \\
Aeromonas hydrophyla & T4 & $0.50(0.12)$ & $0.39(0.10)$ & 1.305 \\
Enterobacter cloacae & & & & \\
Eschenchia coli & T4 & $1.77(0.56)$ & $0.73(0.11)$ & 2.440 \\
& T0 & $1.20(0.39)$ & $0.58(0.15)$ & 2.050 \\
Pseudomonas putida & T4 & $0.70(0.28)$ & $0.45(0.14)$ & 1.564 \\
Salmonella typhimurium & T0 & $1.91(0.71)$ & $0.74(0.07)$ & 2.569 \\
& T4 & $1.18(0.39)$ & $0.62(0.08)$ & 1.905 \\
& T0 & $1.87(0.57)$ & $0.91(0.12)$ & 2.067 \\
& T4 & $0.85(0.34)$ & $0.61(0.08)$ & 1.155 \\
& & $0.86(0.40)$ & $0.79(0.15)$ & 1.804 \\
& & & $0.65(0.09)$ & 1.341 \\
\hline
\end{tabular}

on 1000 permutations) and found a probability $\mathrm{p} \leq$ 0.001 that the observed correlation was obtained by chance, and so we rejected the null hypothesis of random association.

When applied to marine or non-marine strains only, the parameters of the power function (lower and upper $95 \%$ confidence limits) were not significantly different: marine strains: $\alpha=34.34(20.03,44.88), \beta=-0.918$ $(-1.160,-0.722)$; non-marine strains: $\alpha=29.55$ (25.28, $33.80), \beta=-0.749(-0.914,-0.606)$.

Table 2. Mean, standard deviation (SD) and coefficient of variation $(\mathrm{CV})$ of $C_{\mathrm{c}}\left(\mathrm{fg} \mathrm{C}\right.$ cell $\left.{ }^{-1}\right)$ values of each strain

\begin{tabular}{|lccc|}
\hline Bacterial strain & Mean & SD & CV (\%) \\
\hline Marine & & & \\
Alteromonas nigrifaciens & 31.63 & 4.20 & 13.3 \\
Alteromonas rubra & 29.96 & 7.50 & 25.0 \\
Alteromonas tetraodonis & 33.26 & 6.09 & 18.3 \\
Vibrio campbellii & 14.51 & 3.48 & 24.0 \\
Vibrio fischeri & 33.45 & 5.36 & 16.0 \\
Non-marine & & & \\
Aeromonas hydrophyla & 30.59 & 2.84 & 9.3 \\
Enterobacter cloacae & 18.57 & 2.44 & 13.2 \\
Escherichia coli & 24.96 & 4.55 & 18.2 \\
Pseudomonas putida & 21.42 & 5.54 & 25.9 \\
Salmonella typhimurium & 24.07 & 3.00 & 12.5 \\
& & & \\
\hline
\end{tabular}
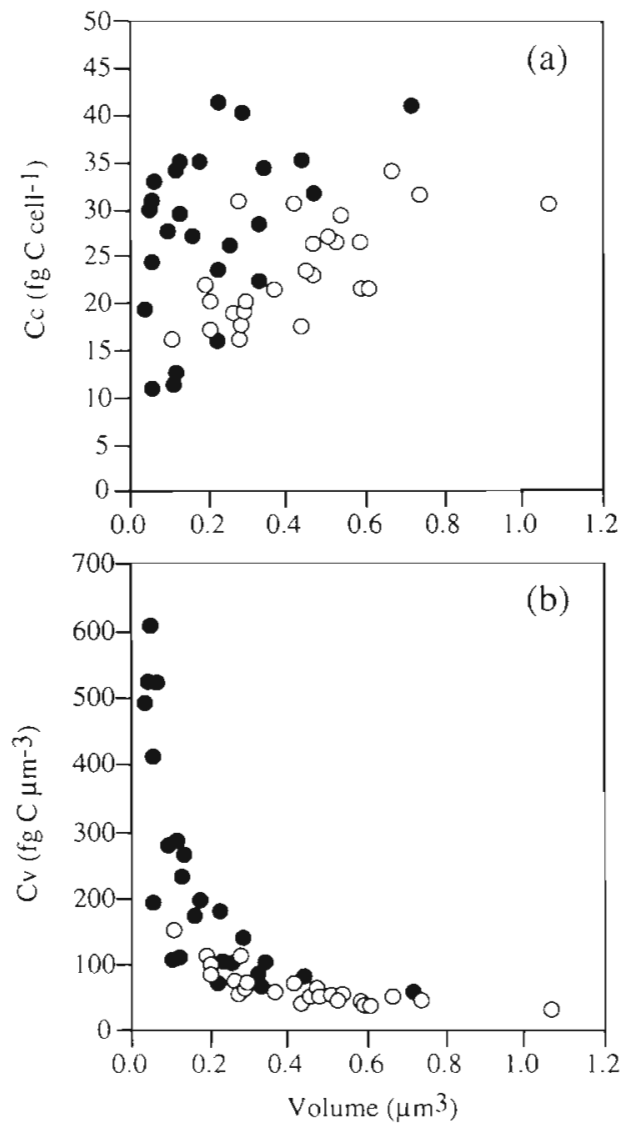

Fig. 3. Relationships between (a) carbon content per cell $\left(C_{c}\right)$ and volume values and (b) between carbon density $\left(C_{v}\right)$ and volume values. (O) Non-marine strains; $(\bullet)$ marine strains

Discussion. Carbon content per cell $\left(C_{c}\right)$ : Regarding the conversion factors among the 10 bacterial species, even if significant differences were shown, carbon content per cell $\left(C_{c}\right)$ was less variable than carbon per

Table 3. Rate of $C_{v}$ increase $\left(d^{-1} ; R^{2}\right.$ and $p$ values in parentheses) as deduced from linear regression model between $C_{v}$ values and duration (d) of starvation incubation

\begin{tabular}{|lr|}
\cline { 2 - 2 } Bacterial strain & Rate \\
\hline Marine & \\
Alteromonas nigrifaciens & $15.14(0.986,0.0007)$ \\
Alteromonas rubra & $1.57(0.948,0.0051)$ \\
Alteromonas tetraodonis & $11.02(0.954,0.0043)$ \\
Vibrio campbellii & $14.27(0.919,0.0101)$ \\
Vibrio fischeri & $16.30(0.914,0.0110)$ \\
Non-marine & \\
Aeromonas hydrophyla & $2.12(0.957,0.0038)$ \\
Enterobacter cloacae & $3.29(0.902,0.0135)$ \\
Escherichia coli & $0.82(0.925,0.0089)$ \\
Pseudomonas putida & $1.90(0.918,0.0103)$ \\
Salmonella typhimurium & $1.97(0.888,0.0164)$ \\
\hline
\end{tabular}


volume $\left(C_{v}\right)$. In fact, a limited decrease of $C_{c}$ values was observed during the first days of starvation. This could be the consequence of short-term degradation of some cellular constituents, such as RNA (Mason et al. 1986, Mason \& Egli 1993, Cabral 1995). The degradation of other major constituents of the cellular carbon content (e.g. protein) is known to show a small decrease during midterm starvation due to the decrease of endogenous metabolism (Mason et al. 1986, Moyer \& Morita 1989).

$C_{c}$ values showed a relatively low range of variation $\left(26.24 \pm 1.08 \mathrm{fg} \mathrm{C} \mathrm{Cell}^{-1}\right.$, mean $\left.\pm \mathrm{SE}\right)$. This value is close to the cell carbon content reported by Lee \& Fuhrman (1987) $\left(20 \pm 0.8 \mathrm{fg} \mathrm{C}\right.$ cell $\left.^{-1}\right)$ and Tuomi et al (1995) (15 to $42 \mathrm{fg} \mathrm{C}^{\mathrm{C}} \mathrm{cell}^{-1}$ ), but lower than average per cell carbon content estimated by Bratbak (1985) (106 to 214 fg C cell ${ }^{-1}$ ), Bjørnsen (1986) (64 $\mathrm{fg} \mathrm{C} \mathrm{cell}^{-1}$ ) or Kroer (1994) $\left(112.9 \pm 68.9 \mathrm{fg} \mathrm{C}\right.$ cell $\left.{ }^{-1}\right)$.

Contribution of measurement errors to the variation of $C_{c}$ obtained in this study is limited, because the mean coefficient of variation associated with replicate measurements of cell counts or POC was low (6.1 and $15.7 \%$, respectively).

Another more probable reason for the $C_{\mathrm{c}}$ variations may be the different experimental conditions for $C_{\mathrm{c}}$ estimations. Most of the data was obtained from growth experiments conducted on filtered natural waters that may be enriched by organic substrates (see Nagata \& Watanabe 1990). As a consequence, measurements were done on cell populations in growth or stationary phase. During these phases, dry weight, protein and nucleic acids content per cell increase (Bremer \& Dennis 1987). Thus, the large differences in $C_{c}$ values reported in the literature may be, at least partly, the result of differences in growth rate depending on nutritional conditions.

Carbon content per volume $\left(\boldsymbol{C}_{v}\right)$ : Clearly, there is a progressive increase in carbon cellular 'concentration' as starvation takes place, but increase rates were very different among species: it was minimal for Escher-

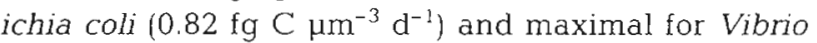
fischeri (16.3 fg C $\mathrm{mm}^{-3} \mathrm{~d}^{-1}$ ). In general, marine strains showed higher $C_{v}$ increase rates than non-marine strains. As a consequence, at the end of the experiment mean values $( \pm S E)$ obtained for marine strains were higher $\left(218.49 \pm 33.32 \mathrm{fg} \mathrm{C} \mu \mathrm{m}^{3}\right)$ than for non-marine

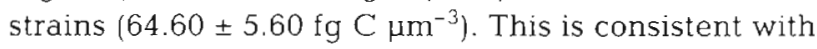
the observations of Nagata \& Watanabe (1990).

The carbon to volume ratio is directly related to the water content of bacteria which in turn depends on the osmotic conditions in the cell (Fagerbakke et al. 1996). If we assume, following Bjørnsen (1986), a partial dry matter density of $1.6 \mathrm{~g} \mathrm{~cm}^{-3}$ and a $50 \%$ carbon/dry weight ratio, $C_{v}$ values higher than $500 \mathrm{fg} \mathrm{C} \mathrm{mm}^{-3}$ would imply very high dry matter content $(>60 \%)$ or low water content $(<40 \%)$. Such high $C_{\mathrm{v}}$ values have been observed only for marine strains at the end of starvation periods. From the power-function equation, it may be shown that values higher than $500 \mathrm{fg} \mathrm{C} \mathrm{mm}^{-3}$ would be obtained for cellular volumes lower than $0.05 \mathrm{\mu m}^{3}$. These low values were only reached by marine strains (min. $0.04{\mu \mathrm{m}^{3}}^{3}$ ), while lowest values for

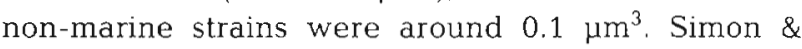
Azam (1989) have already reported that marine diminutive bacteria are very 'dry'.

So, we can hypothesize that the highest mean values and increase rate of $C_{v}$ for marine strains starved in ASW are the consequence of a faster decrease of their water content than for non-marine strains starved in PW.

As suggested by different authors, the variability of $C_{v}$ values in the literature is probably caused by the use of different criteria to estimate the size of bacterial cells. This effect was supposed to be reduced in our study, because cell dimensions were measured in the same way. We obtained no significant relationship between the coefficient of variation and mean values of cell volume. Therefore, most of the variation in our data may be attributed to species and starvation effects.

$C_{c}$ and $C_{v}$ versus volume relationships: The increase of $C_{v}$ was significantly correlated with the decrease of mean cell volume (Fig. 3b). This relationship was observed for each strain during the incubation period (data not shown). On the whole, a power function was used to fit the data because of the non-linear form of the relationship, as already reported by Lee \& Fuhrman (1987). This model indicates that $C_{v}$ of the cells increases greatly as the cellular volume decreases. The parameters of the equations were not significantly different for marine and non-marine strains. This is consistent with the non-significant differences between cell volume:protein relationships for freshwater and marine natural bacterial assemblages reported by Simon \& Azam (1989). However, in spite of careful statistical analysis (see 'Results' section), the fact remains that there is no biological interpretation of the parameters of these equations (Norland 1993).

Despite the relatively small number of bacterial species used in this study, our results support the hypothesis that $C_{v}$ and, to a lesser extent, $C_{c}$ values are species dependent. $C_{\mathrm{v}}$ is also greatly affected by starvation conditions. However, it seems that the differences in $C_{\mathrm{v}}$ between marine and non-marine bacteria observed in this study and by others (Nagata \& Watanabe 1990) are not the consequence of different relationships between $C_{\mathrm{v}}$ and volume but, more likely, of lower cell volume and its faster decrease for marine bacteria than for non-marine bacteria. The cell shrinkage process may be a general adaptative process to 
starvation or sharp nutrient limitation, which may be more frequently experienced by marine than by nonmarine bacteria. An increase in the surface/volume ratio of cells, which is achieved by reduction of cell size, may facilitate the uptake of scarce substrates (Gottschal 1992). Size reduction may also lead to minimization of maintenance requirements (Oliver 1993). The mechanism whereby marine bacteria, starved in artificial seawater, reduce their water content faster than do non-marine bacteria in physiological water remains unclear and merits further examination.

Acknowledgements. We are grateful to Evelyne Gavinelli (ORSTOM) for the particulate organic carbon measurements. We also thank Philippe Lebaron (Laboratoire Aragol for providing bacterial strains of marine origin, and Pierre Legendre (Université de Montrêal) for his statistical assistance.

\section{LITERATURE CITED}

Bjørnsen PK (1986) Automatic determination of bacterioplankton biomass by image analysis. Appl Environ Microbiol 51:1199-1204

Bratbak G (1985) Bacterial biovolume and biomass estimations. Appl Environ Microbiol 49:1488-1493

Bremer H, Dennis PP (1987) Modulation of chemical composition and other parameters of the cell by growth rate. In: Neidhardt FC (ed) Escherichia coli and Salmonella typhimurium cellular and molecular biology, Vol 1. ASM, Washington, DC, p 1527-1542

Cabral JPS (1995) Viability and respiratory activity of Pseudomonas syringae cells starved in buffer. Can J Microbiol 41:372-377

Chayes F (1971) Ratio correlation. University of Chicago Press, Chicago

del Giorgio PA, Scarborough G (1995) Increase in the proportion of metabolically active bacteria along gradients of enrichment in freshwater and marine plankton: implications for estimates of bacterial growth and reproduction rates. J Plankton Res 17:1905-1924

Ducklow HW, Carlson CA (1992) Oceanic bacterial production. In: Marshall KG (ed) Advances in microbial ecology. Plenum Press, New York, p 113-181

Fagerbakke KM, Heldal M, Norland S (1996) Content of carbon, nitrogen, oxygen, sulfur and phosphorus in native aquatic and cultured bacteria. Aquat Microb Ecol 10: $15-27$

Responsible Subject Editor: G. Bratbak, Bergen, Norway
Gottschal JC (1992) Substrate capturing and growth in various ecosystems. J Appl Bacteriol Symp Suppl 72:93-102

Jackson DA, Somers KM (1991) The spectre of 'spurious' correlations. Oecologia 86:147-151

Kroer N (1994) Relationships between biovolume and carbon and nitrogen content of bacterioplankton. FEMS Microbiol Ecol 13:217-224

Lee S, Fuhrman JD (1987) Relationships between biovolume and biomass of naturally derived marine bacterioplankton. Appl Environ Microbiol 53:1298-1303

Mason CA, Egli T (1993) Dynamics of microbial growth in the decelerating and stationary phase of batch culture. In: Kjelleberg $S$ (ed) Starvation in bacteria. Plenum Press, New York, p 81-102

Mason CA, Hamer G, Bryers JD (1986) The death and lysis of microorganisms in environmental processes. FEMS Microbiol Rev 39:373-401

Morita RY (1993) Bioavailability of energy and the starvation state. In: Kjelleberg $S$ (ed) Starvation in bacteria. Plenum Press, New York, p 1-2.3

Moyer CL, Morita RY (1989) Effect of growth rate and starvation-survival on cellular DNA, RNA, and protein of a psychrophilic marine bacterium. Appl Environ Microbiol 55: $2710-2716$

Nagata $T$ (1986) Carbon and nitrogen content of natural planktonic bacteria. Appl Environ Microbiol 52:28-32

Nagata T, Watanabe Y (1990) Carbon- and nitrogen-tovolume ratios of bacterioplankton grown under different nutritional conditions. Appl Environ Microbiol 56: $1303-1309$

Norland S (1993) The relationship between biomass and volume of bacteria. In: Kemp PF, Sherr BF, Sherr EB, Cole JJ (eds) Handbook of methods in aquatic microbial ecology. Lewis Publishers, Boca Raton، p 303-307

Oliver JD (1993) Formation of viable but nonculturable cells. In: Kjelleberg $\mathrm{S}$ (ed) Starvation in bacteria. Plenum Press, New York, p 239-272

Roszak DB, Colwell RR (1987) Survival strategies of bacteria in the natural environment. Microbiol Rev 51:365-379

Simon M, Azam F (1989) Protein content and protein synthesis rates of planktonic marine bacteria. Mar Ecol Prog Ser 51:201-213

Sokal RR, Rohlf FJ (1981) Biometry. WH Freeman and Company, San Francisco

Troussellier M, Courties C, Vaquer A (1993) Recent applications of flow cytometry in aquatic microbial ecology. Biol Cell 78:111-121

Tuomi P. Fagerbakke KM, Bratbak G. Heldal M (1995) Nutritional enrichment of a microbial community: the effects on activity, elemental composition, community structure and virus production. FEMS Microbiol Ecol 16:123-134

Manuscript received: September 30, 1996

Revised version accepted: February 4, 1997 